\title{
現地データを基にした貯水池内濁水流の挙動に関する考察 \\ Study on turbid water current penetrating into dam reservoir through field measurments
}

$\begin{array}{llll}\text { 東京理科大学理工学部 } & \text { 正 } \text { 員 } \text { 西 外 明 } \\ \text { 電源開発株式会社 } & \text { 正 員 喜多村 雄 一 }\end{array}$

\section{1.はじめに}

河川流域加生産される土砂による眝水池の濁水長期化現象は, 下流水域の環境問題に関係した重要な研 究問題である。水理学の分野では, 眝水池の上流より流入する濁水の挙動は, 密度流の代表的な問題の一つ として従来から研究されてきている。しかしその多くは数值解析, 理論解析および模型実験によるあのであ り，琴地における観測データを基にした検討例は少ないように思われる。また，眝水池内での濁水の挙動の 解析においても，眝水池を無限大の水域と仮定するてとが多い。しかし，現実の眝水池では下流端のダムの 存在が, 池内の濁水流の挙動や, 眝水池内の濁水分布を支配するととが予測されることからダムと濁水との 干涉現象を知ることは，眝水池の濁水長期化防止対策を立案する上で重要であると考えられる。

以上の観点から，本論文では実際のダム眝水池におりる水温と濁度の測定結果を用いて，有限な眝水池内 の濁水洪水流挙動を把握し，さらにそれを支配する水理学的な機構を実験と解析とにより明らかにすること を試みる。

\section{2. 貯水池内流動状態の現地観測}

$\mathrm{K}$ ダム眝水池では, 1973 年以来, 各月に最低 1 回（最高 7 回）, ダム軸より上流 $200 \mathrm{~m}, 2,160 \mathrm{~m}$, $4,000 \mathrm{~m}, 6,280 \mathrm{~m}, 7,700 \mathrm{~m}, 10,060 \mathrm{~m}, 11,870 \mathrm{~m}, 13,040 \mathrm{~m}, 13,930 \mathrm{~m}$ の所什 8 ケの測定断面を設定して, 水温と濁度の鉛直分布を測定している。この貯水池では, 1976 年 6 月末に 表層取水設備が設置され, 同年 7 月 26 日より表層取水を行って下流河川水の濁度軽減化を計っている。乙 こでは, ダムと濁水流との関連を見るために，冬期に人工的に水位低下を行った 1976 年 1 月から 6 月ま での池内の現象を検討の対象とする。図 1 から図 10 は, この期間に得られた測定值から池内の等濁度線 と 水温の分布を求めて, 季節毎に, 眝水池内の濁水の流動状態を図示したものである。四中で点線は水温 $\left({ }^{\circ} \mathrm{C}\right)$ 実線は等濁度線 $(\mathrm{ppm})$ を示している。なお, 各観測月の眝水池への流入量 $\left(\mathrm{Q}_{i}\right)$, 池外への流出量 $\left(\mathrm{Q}_{0}\right.$, 発電取水量とゲート放流量の和）は表 1 亿示すと打りである。図 1 と図 2 に示す冬期には, 眝水位が低く, 水温は鈶直方向に一様である。このような水域へ上流から流入した濁度（密度）の高い河川水は, 池内では 底首流となってダムに近づき，そてでその厚さを増している。それは, 周囲水よりも密度が大きい底首流が, ダム背面に衝突して生じる段波の存在を示唆してると考えられるが，ての現象については後節において詳細

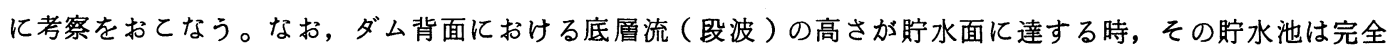
混合型となると考えられる。2月 27 日（図 3 ）の場合には，流入水の濁度は，池内水よりあ小さく，また， 表層水温が池内水温に比べて高くなっているために, 流入水は支川の合流部の上流で河床より剥離して, そ れより下流では表層流となって, 発電所取水口へ流入している。剥離点の直下流の底層部では濁度が $30 \mathrm{ppm}$ から $90 \mathrm{ppm}$ 以上に急増しているが，それは剥離時の乱れによって底質がまき上げられるてとによると考え られる。表層と底層の間の内部境界面が安定を保っているととから, 流入量 $\left(\mathrm{Q}_{i}\right)$ と流出量 $\left(\mathrm{Q}_{o}\right)$ が共に比 比較的少なかったあのである。なお，底層部には高濁度の池水が停滞しているのが認められる。

3 月 5 日（図 4 ）の場合には, ダム直上流の取水口敷以下の所飞軽微な水温躍層面が形成されており, そ れより下層では約 $300 \mathrm{ppm}$ 以上の濁水が停滞している。当日の池内への流入量は本川から $34.25 \mathrm{~m}^{3} / \mathrm{s}$, 
支川から $9.45 \mathrm{~m}^{3} / \mathrm{s}$, 計 $43.7 \mathrm{~m}^{3} / \mathrm{s}$ であり, 一方, 発電取水量は $59.6 \mathrm{~m}^{3} / \mathrm{s}$ であ。この日の使用水量 量は, 取水口敷 ( EL. $247.4 \mathrm{~m}$ ) から水面までの厚 さ4 4 mの表層流として眝水池上流より流れ込んでい る。そのさいの内部境界面は, 平均的にはほぼ水平で あるが, 不安定化して大きく波立っているのが認めら れる。上流からの流入水は下流にいくほど増加し, 断 面 6 付近で池底より剥雕して, それより下流では取水 ロに向う流れは中間層流となっている。てのように， 従来の眝水池濁水現象のシシミュレーション解析では,

“流水中の浮遊土砂が流下につれて沈降するために, 下流部ほど濁度が低下する”と考えることが多い。し 加し, この場合は水位低下に伴う生産土砂を含む池水 のまき上げの方が池水の濁り分布に大きく寄与してい るととがわかる。また, 図 4 によれば, 支川合流部で は流水断面積が急増するために, 流れの状態が急に変 表 1 観測月の流量 (月平均)

\begin{tabular}{|c|c|c|c|c|}
\hline 月 & $\begin{array}{c}\text { 流入量 } \\
\left(m^{3} / \mathrm{s}\right)\end{array}$ & $\begin{array}{r}\text { 流出量 } \\
\left(\mathrm{m}^{3} / \mathrm{s}\right)\end{array}$ & $\begin{array}{c}\text { 眝水位 } \\
(m)\end{array}$ & 摘 \\
\hline 1 & 8.7 & $\begin{array}{r}28.8 \\
5.5 \\
\end{array}$ & 266.96 & \multirow{6}{*}{$\begin{array}{l}\text { 流出量の } \\
\text { 上段は発 } \\
\text { 電取水量, } \\
\text { 下段はゲ } \\
\text { 一ト放流 } \\
\text { 量である。 }\end{array}$} \\
\hline 2 & 44.5 & $\begin{array}{l}9.5 \\
1.3 \\
\end{array}$ & 264.01 & \\
\hline 3 & 38.1 & $\begin{array}{c}36.8 \\
0\end{array}$ & 288.35 & \\
\hline 4 & 37.8 & $\begin{array}{c}43.0 \\
0\end{array}$ & 285.34 & \\
\hline 5 & 56.0 & $\begin{array}{c}58.4 \\
0 \\
\end{array}$ & 283.16 & \\
\hline 6 & 99.0 & $\begin{array}{l}85.1 \\
30.0\end{array}$ & 280.04 & \\
\hline
\end{tabular}
化して, 底面からの剥離現象が再び発生している。底層水は, こてであダム背面に衝突して段波を生じっつ その高濁度の水塊が移流してダム背部の池底に停滞している。

3 月 13 日（図 5 ）の場合, ダムの直上流の取水口標高以下の水域には比較的低い水温の水塊が停滞して いる。乙の場合も, 眝水池上流部の表層の濁度は底層を連行しながら下流にいくにつれて増加している。3 月 26 日（困6）と 4 月 13 日（図 7 ）には上層水の剥離線は池底にほぼ直交している。その原因としては 1）発電取水量が急に減少するてと，口）支川からの流入により，下流の流量が上流部よりあ多くなるとと， 八）ダム背面で段波が生じるとと, 二）下流の流体密度が高濁度, 低水温のために上流側の密度よりあ大き くなるとと等が考えられる。

5 月 13 日（図 9 ）には, 眝水位が EL. $282.32 \mathrm{~m}$ に低下しており, また発電取水量が多いために, 池 底部の高濁度の水塊が, 取水口標高と等しい高さの池底付近加ら表層流内へ連行されている。てのように, 底部の澱み水の表層流内への連行は, ダム背面と直接に接しているケ所においてではなく, 表層流が池底に 接する断面付近において生じる。

この流域では 1976 年 6 月 10 から同月 13 日の間俍大 $510.0 \mathrm{~m}^{3} / \mathrm{s}-\mathrm{H}$ の出水があった。四 10 は, その出水後の 6 月 15 日に測定した結果である。この間には, 最大発電用の $60.0 \mathrm{~m}^{3} / \mathrm{s}$ のほかに 330.0 $\mathrm{m}^{3} / \mathrm{s}$ の池水をクレストゲートから堤外へ放流した。同図に見られるように，ダムに向う池水の流れは，ク レストゲートに向う高温の表層流と取水口へ向う中間層流とに明確に層分離されている。ただし, 流入量が 流出量を上まわるために, ダム背面での中間層の厚さが増加し（段波発生）, それが上流へ向って逆流して いく状態が認められる。図 10 によれば中間層流がダム背面に当って段波を発生させる場合, 中間層流の厚 さの増加は上部の内部境界面の上昇の形をとり，下部の内部境界面を下降させるととが少ないと考えられる。

以上の検討結果を要約すると

（1）水位の低い貯水池容量に比較して流入量が大きく，かつ流入水の密度が眝水池水密度よりあ大きい時に は底層流としてダム背面に達して段波を生じる。段波高さが取水口㜞に達しない場合には, 濁質は眝水池 内によどまる。

(口) 眝水位がある程度以上に高いときには, 池水は取水口敷高標高付近を境として, それ以下の洀み層とそ の上部の流動層にわかれる。

(、) 下層の溊み水塊の流動層内への混入は, 内部境界面の全面的な破壊過程によってではなく, 流動層が池

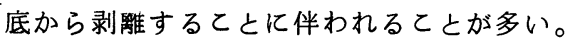



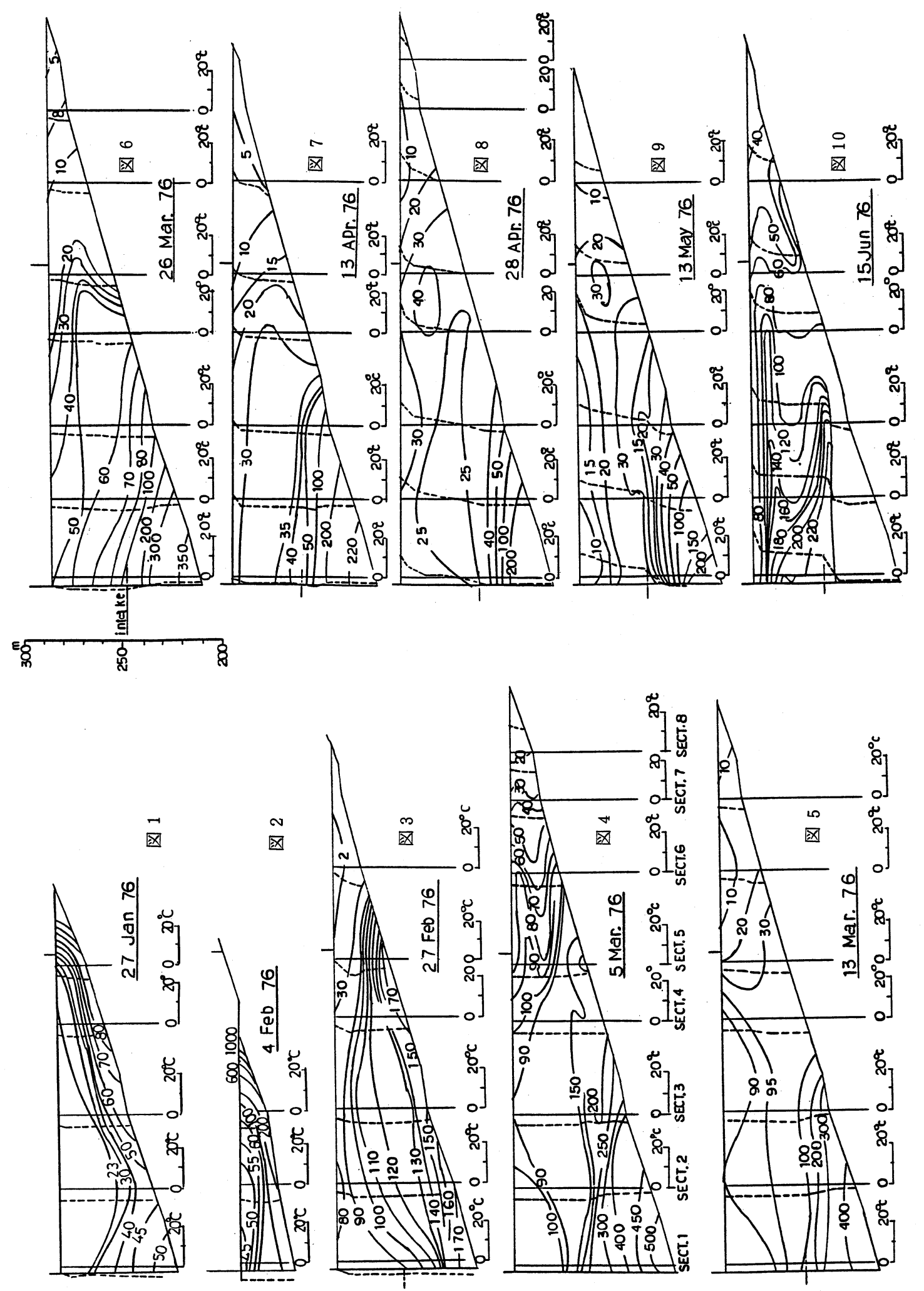
(二) 眝水池上流端から流入した河川水は底質を連行しながら濁度（密度）増すが, 一方, 流水断面積が増 すために流速が低下する。一般に眝水池では, 池水の密度は主として水温により支配されるために, 底層 流は濁度を増すにあかかわらず池底から剥截する。

(ホ) 剥離は支川合流点の前之後，および取水口敷休付近の三ヶ所でおきやすい。

(へ) 池内へ侵入する中間層流がダムに達してその厚さを増すさい, 上部の内部境界面の上昇を伴い, 下部界 面の変化は比較的少ない。

\section{3. タム背面で生じる段波についての解析的検討}

上記の現地観測結果を基にすると，眝水池の濁水長期化現象を考える場合，又，濁水長期化防止策を考え る上でダム背面で発生する段波高さを知るととが必要である。

いま, 図 11 亿示す様な底が水平面に 対して $\theta^{\circ}$ 傾斜する 2 次元的形状をむ。 た眝水池を想定する。池の上流加ら水深 $h_{1}$, 流速 $V_{1}$, 密度 $\rho_{1}$ の底層流が流入 して, それがダム背面に達して運動エネ ルギーが位置エネルギーに変換されて, 高さ $h_{d}$ の段波が発生したとする。ダム からの放流がない場合は，段波内での流 速は 0 と考えてよい。ダム背面における 反射時の混合を無視すると，I〜II断面 間の下層水塊（図 11 参照）に作用する 水平方向の力は水压 $P_{1}, P_{2}, P_{3}$ (図 11 ) と底ぞいの摩擦力 Fの分力であるから，

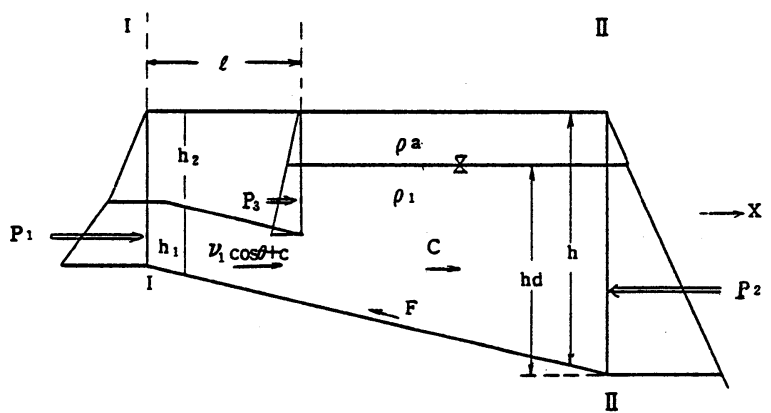

図11 解析モデル

運動量方程式は

$$
P_{1}-P_{2}+P_{3}-F_{\cos } \boldsymbol{\theta}=\rho_{1} C^{2} h_{d}-\rho_{1}\left(V_{1} \cos \Theta+C\right)^{2} h_{1}
$$

ここに，Cは段波の遡上速度である。周囲の池水の密度を $\rho_{a}$, 断面 I における池の水深を $h_{2}$ とする，水 圧 $P_{1}$ と $P_{2}$ はそれぞれ次式で与えられる。

$$
\begin{aligned}
& P_{1}=\rho_{a} g h_{2} h_{1}+\frac{\rho_{1} g h_{1}^{2}}{2} \\
& P_{2}=\rho_{a} g\left(h-h_{d}\right) h_{d}+\frac{\rho_{1} g h_{d}^{2}}{2}
\end{aligned}
$$

ただし， $g$ は重力の加速度， $h$ はダム背面における貯水池の全水樑である。また，断面 I と段波面との間の 水平距離を $\ell$ とすると, $P_{3}$ は次式で表わされる。

$$
P_{3}=\frac{\rho_{a} g}{2}\left\{\left(h_{2}+\ell+\tan \Theta\right)^{2}-(h-h d)^{2}\right\}
$$

自然河川では一般に $\theta$ は小さく， $h_{2} \gg \ell \tan \theta$ と考えることができるので，上式は次のように近似化される。

$$
P_{3} \simeq \frac{\rho_{a} g}{2}\left\{h_{2}^{2}-\left(h-h_{d}\right)^{2}\right\}
$$

(1)に(2)〜 (4)を代入して, $\theta \simeq 0$ とおくと運動量の方程式は次式となる。 


$$
\frac{g^{\prime}}{2}\left(h_{a}^{2}-h_{1}^{2}\right)+\frac{F}{\rho_{1}}=\left(V_{1}+C\right)^{2} h_{1}-C^{2} h d
$$

乙てに,

$$
g^{\prime}=\left(\rho_{1}-\rho_{a}\right) g / \rho_{1}
$$

$F=0$ とすると，(5)は

$$
\frac{g^{\prime}\left(h_{d}^{2}-h_{1}^{2}\right)}{2}=\left(V_{1}+C\right)^{2} h_{1}-C^{2} h_{d}
$$

また, 眝水池の単位幅当りの流量を $q$ とすると, $\theta \simeq 0$ の時の連続の式は

$$
q=\mathrm{V}_{1} h_{1}=C\left(h_{a}-h_{1}\right)
$$

(7)に(8)を代入すると次式をうる。

$$
\frac{1}{2}\left(h_{1} d+h_{1}\right)=\frac{q^{2} h d}{g^{\prime}\left(h d-h_{1}\right)^{2} h_{1}}
$$

いま, 底首流の内部フルード数 $F_{r}$ を次式で定義する。

$$
F_{r}=V_{1} / \sqrt{g^{\prime} h_{1}}
$$

(9)と(10)より, 結局, 次式をうる。

$$
F_{r}=\frac{\left(1-h_{1} / h_{d}\right)}{\sqrt{2}\left(h_{1} / h_{d}\right)} \sqrt{1+h_{1} / h_{d}}
$$

\section{4. 水理模型実験による検討}

上記の解析結果の妥当性を確めるために水理模型実験を行なった。実験水槽は長さ $4 m \times$ 幅 $0.2 m \times$ 深さ $0.6 m$ の両面透明な耐压ガラス製である（図 12 ）。上流より流入する洪水を模擬した塩水は幅 $0.6 m \times$ 高さ

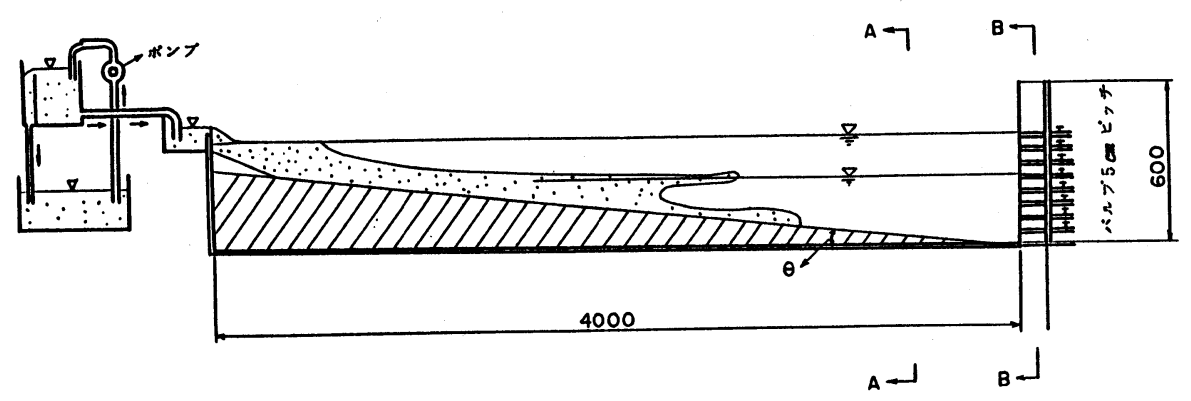

図 12 実 験 水 槽

$0.6 m \times$ 深さ $0.6 m$ の高架水槽で所定の密度をむつ樣に調合したのち, 実験水槽上流部より供給した。その 供給流量は管路の途中に設けたバルブにより調整した。なお, その供給流量を実験中一定に保つために, 高 架水槽内の塩水の水面は常に余水吐面と一致させるようにした。実験水槽の下流端には, 高さ $5 \mathrm{~cm}$ ごとに径 $0.5 \mathrm{~cm}$ の排水口を設けて, 下流端バルブを開閉するととにより, 放水口の位置と放流量を自由に選定しうる ようにした。なお, 実験水槽内の流れが横断方向に一様化させるために一流れの 2 次元性を保たせるため に一実験水槽下流端の長さ $30 \mathrm{~cm}$ の区間を高さ $5 \mathrm{~cm}$ 毎に分割し, それぞれの部分に上記の排水孔を設けた。 水路底の形状は, 図13に示すように下流部に $80 \mathrm{~cm}$ の水平部をとり, その上流を $\tan \theta=2.667$ とした場 
合（ $\mathrm{A}$ シリーズ）と, 底全体を $\tan \theta=0.225$ とした場合（ $\mathrm{B}$ シリーズ）について実験を行った。

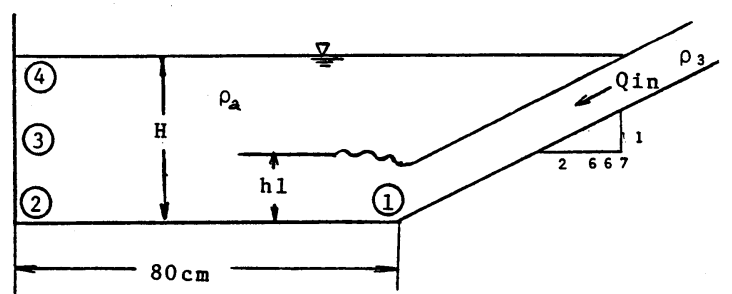

(a) I 型（Aシリーズ $)$

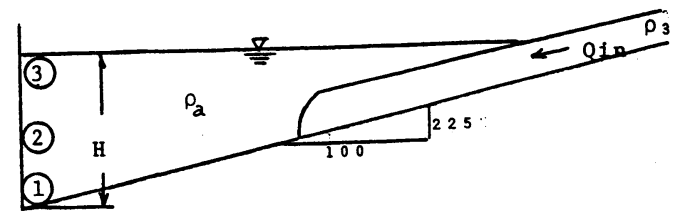

(b) II 型( $\mathrm{B}$ シリーズ )

図 13 実験水路の底形状と流体の比重測定点

実験では, 貯水池水深, 流体密度, 流量を変化させて, 底層密度流の形状と速度を自動駆動式カメラとビ デオによって測定した。また，底層流が上流の傾斜部を経てダム背面に達するまでに，周囲水との混合によ り, その流体密度を変化させていく状態を知るために, 図(13)に示した測点に電気伝導度計を設置した。なお, 流体密度の測定には比重計をす併用した。

実験の結果, 底層流の密度は池内への流入点（測点(1) ) 飞おいて, 周囲水の混入（本実験では, 供給流量 の約 10 倍のオーダ）により, 高架水槽内の流体密度より小さくなるが, それ以後の変化は軽微であるてとが 認められた。そてで, 底層流の密度として, 池内への潜り込み後の測点(1)密度を用い, また, その水深と して写真上より測った值を採用して, 式(10)により $F_{r}$ を求めて, 式(11)の関係をプロットすると図14のようにな る。なお， B シリーズの場合の $F_{r}$ は $F_{r}=\mathrm{V}_{1} \cos \theta / \sqrt{g^{\prime} h_{1}}$ により算定した。

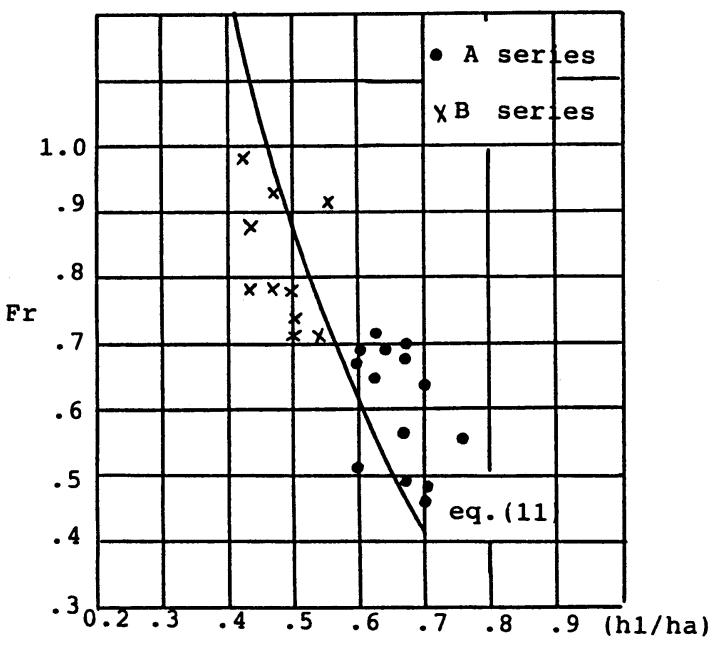

図 14 底層流の特性と段波高の関係

また，図15と図16に底層流の流速に関する実験結果を示す。図14 によれば, 式(11)の解が実験値と良い一致を示している。また, 底 層流の流速の実験式 (図中の(12), (13)) は, 全水深の $1 / 2$ さをもつ底層 流の解 $V_{1}=\frac{1}{2} \sqrt{g^{\prime} h_{1}}$ に近い值を示している。 ${ }^{1)}$

\section{5. おわりに}

現地観測データにより，貯水池内の濁水分布を解析するさい, ダムと濁水流との干涉現象が重要であるこ とを示した。内部界面上を流入する濁水流の解析と実験については後日報告する予定である。

参考文献 1) Turner, J.S. : Buoyancy effects in Fluid (Cambridge Pr.) P. 73。

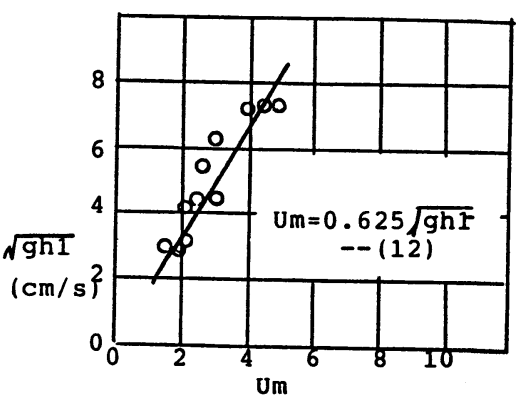

図 15 底層流の流速 ( $\mathrm{A}$ シリーズ )

$\sqrt{\text { gh1 }}$

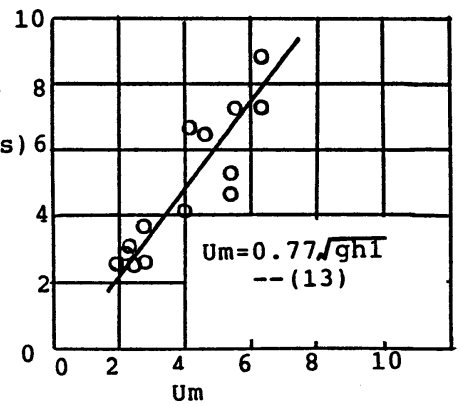

図 16 底層流の流速 ( $\mathrm{B}$ シリーズ ) 